\title{
NOTE ON AN ELECTRICAL CONDUCTANCE METHOD FOR DETERMINING LIQUEFACTION TEMPERATURES OF SOLIDS
}

\author{
By Edward W. Washburn and Edgar R. Smith
}

\section{ABSTRACT}

A conductance method for measuring liquefaction temperatures, which requires only a few milligrams of the substance investigated, is described. The method has been applied to the determination of eutectic temperatures of water-salt systems and to the determination of transition temperatures of salt hydrates. The method is applicable to any system which is practically a nonconductor of electricity below the liquefaction temperature and which abruptly exhibits an appreciable conductance at this temperature.

\section{CONTENTS}

I. Introduction

II. Experimental procedure

III. Apparatus and method.

IV. Experimental results

\section{INTRODUCTION}

When a solid or a mixture of solids behaves as an electrical insulator below its liquefaction temperature but becomes a conductor as soon as the liquid phase appears, the temperature at which the system acquires this electrical conductance will be the liquefaction temperature of the system. This paper describes an apparatus for determining this temperature and gives some experimental results obtained in applying the method to the determination of eutectic temperatures and of incongruous melting points of salt hydrates.

The method will be found especially convenient where only small quantities of material are available. It has the additional advantage, in comparison with other methods, of being unaffected by the presence of any impurity which does not lower the initial liquefaction temperature. It will give reliable results in many cases in which the customary methods fail for any of the following reasons:

1. Because of the presence of impurities soluble in the liquid phase.

2. Because of a small latent heat of liquefaction which renders the equilibrium method, the calorimetric method, or the method of thermal \&nalysis unreliable. 
3. Because of the acuteness of the angle of intersection of the solubility curves in the case of the solubility method.

4. Because of a small volume change on liquefaction in the case of the dilatometer method.

\section{EXPERIMENTAL PROCEDURE}

For the determination of eutectic temperatures of aqueous systems containing at least one electrolyte the method consists essentially in applying a voltage across the electrodes of a cell filled with ice in contact with the solid electrolyte or mixture in question. The cell is immersed in a well-stirred bath below the eutectic temperature and is connected with a galvanometer. The temperature of the bath is allowed to rise slowly. When the eutectic temperature is reached, solution forms in equilibrium with the solid mixture and causes a marked increase in conductance. At this point the galvanometer deflects and the corresponding temperature is measured by means of a thermometer immersed in the bath. For the measurement of a melting point a similar procedure is followed.

\section{APPARATUS AND METHOD}

After experimenting with several arrangements, the apparatus (fig. 1) finally adopted consists of an iron cell, shown to scale in the figure, containing a platinum-wire electrode sealed in the glass tube which projects through the bottom of the cell. The cell serves as the other electrode. During the measurement it is immersed in a well-stirred bath of merFIG. 1 cury precooled below the temperature to be measured and contained in a Dewar tube. If a eutectic temperature is to be measured, the cell is first partly filled with water, which is then frozen so that the end of the platinum wire extends through the surface of the ice. A few milligrams of the powdered electrolyte are placed on the ice surface around the electrode, ${ }^{1}$ the cap is screwed into place, and the cell is completely immersed in the bath close to the bulb of a thermometer. The cell is connected in series with the heating element of a vacuum thermocouple and with the 6-volt

1 A little melting and immediate refreezing might occur when the warmer particles first touch the ice surface. The result would be a thin surface layer of frozen eutectic mixture which would do no harm and might even be an advantage. 
terminals of a small transformer operated on the 60-cycle 110-volt line. The thermocouple leads are connected to the terminals of a galvanometer. The galvanometer used had a voltage sensitivity of $0.3 \mathrm{~mm}$ per microvolt and was suitably damped when connected to the thermocouple. The temperature of the bath is allowed to rise slowly, and when the galvanometer shows a deflection the reading of the thermometer is taken as the eutectic temperature. It is worth noting that the galvanometer deflection is proportional to the square of the conductance, since the heat developed at the thermocouple junction is proportional to the square of the current. The successful use of the thermocouple and galvanometer arrangement depends largely on this second power proportionality.

It was found best, in order to obtain results reproducible to about 0.02 to $0.03^{\circ}$, to keep the circuit open until the temperature is within 0.1 to $0.2^{\circ}$ of the eutectic point; otherwise the small current across the solid mixture may cause a cumulative heat effect within the cell resulting in the formation of solution and a marked increase in conductance before the outside bath has reached the eutectic temperature. The experimental fact that, with the circuit continuously closed, larger impressed voltages may result in deflections at lower temperatures seems to bear out this conclusion. For this reason, the circuit is closed only momentarily every $0.02^{\circ}$, starting 0.1 to $0.2^{\circ}$ below the eutectic temperature and continuing until slightly above. A preliminary experiment may be necessary in some cases to establish the approximate location of the eutectic point.

If a melting point is to be measured, the cell is filled with the dry salt below the desired temperature and the same procedure is followed.

TABLE 1.-Temperature galvanometer readings for the system $\mathrm{K}_{2} \mathrm{SO}_{4}-\mathrm{H}_{2} \mathrm{O}$

\begin{tabular}{|c|c|c|}
\hline $\begin{array}{c}\text { Temper- } \\
\text { ature }\end{array}$ & $\begin{array}{c}\text { Galva- } \\
\text { nometer } \\
\text { deflection }\end{array}$ & $\begin{array}{c}\text { Galva- } \\
\text { nometer } \\
\text { deflection }\end{array}$ \\
\hline${ }^{\circ} C$. & $m m$ & $m m$ \\
-1.61 & 0 & 0 \\
.59 & 0 & 0 \\
.57 & 0 & 0 \\
.55 & 0 & 0.5 \\
.53 & 1 & 2 \\
.51 & 6 & 8 \\
.49 & 20 & 35 \\
\hline
\end{tabular}

A verage eutectic temperature, $1.54^{\circ}$.

\section{EXPERIMENTAL RESULTS}

\section{EUTECTIC TEMPERATURES}

Typical temperature and galvanometer readings obtained by the method outlined are shown in Table 1 for two experiments with potassium sulphate and water. In order to give the method a further test, the eutectic temperatures of several salts and of a salt mixture were 
measured and compared with the values obtained by investigators using the equilibrium method with large quantities of the salts. These results are summarized in Table 2. Each result given in the table is the average of two or three determinations agreeing to within 0.02 to $0.03^{\circ}$. The known values were taken from Landolt-Börnstein Tabellen, fifth edition, and International Critical Tables. It is evident, from the comparison of the known eutectic temperatures with the measured values for the salts given in the table, that the method gives results which are correct within its own degree of precision. Temperature lag between the bulb of the Beckmann thermometer and the contents of the cell and, perhaps, the time required for the spreading of a finite film of solution over the surface of the ice may account for the variability observed. The use of a small thermocouple placed within the cell instead of the thermometer in the bath would probably reduce the temperature lag and eliminate the variability due to this cause.

TABLE 2.-Eutectic temperatures measured by the conductance method compared with their known values

\begin{tabular}{|c|c|c|}
\hline Electrolyte & $\begin{array}{l}\text { Eutectic } \\
\text { tempera- } \\
\text { ture by } \\
\text { conduct- } \\
\text { ance }\end{array}$ & $\begin{array}{l}\text { Known } \\
\text { eutectic } \\
\text { tempera- } \\
\text { ture }\end{array}$ \\
\hline 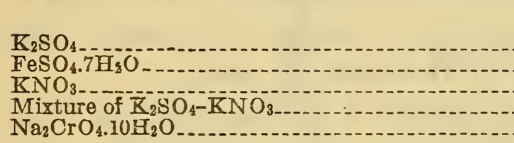 & $\begin{array}{l}{ }^{\circ} \mathrm{C} . \\
-1.54 \\
-1.80 \\
-2.84 \\
-3.27 \\
-4.92\end{array}$ & $\begin{array}{l}{ }^{\circ} \mathrm{C} . \\
-1.55 \\
-1.821 \\
-2.9 \\
-3.3 \\
-4.9\end{array}$ \\
\hline
\end{tabular}

\section{INCONGRUENT MELTING POINTS}

The temperature at which the dekahydrate of sodium sulphate is in equilibrium with the anhydrous salt and solution and the temperature at which the dekahydrate of sodium chromate is in equilibrium with the hexahydrate and solution are known to an accuracy of about $0.001^{\circ}$ and are used as fixed points in thermometry. ${ }^{2}$ These transition temperatures were measured by the conductance method and furnish a reliable test of the method for such systems. The thermometer used for this purpose was graduated in $0.2^{\circ}$ divisions and had a Bureau of Standards calibration certificate. It was further standardized at the transition temperature of the dekahydrate of sodium sulphate $\left(32.384^{\circ}\right)$ by inmersing it in a Dewar tube filled with the equilibrium mixture at this temperature. The temperatures found by the conductance method are compared with the known values in Table 3. Corrections were applied for the emergent stem.

${ }^{2}$ Richards and Wells, Proc. Am. Acad., 38, p. 431; 1902. Dickinson and Mueller, B. S. Bull. 3, p. 641; 1907. Richards and Kelly, Proc. Am. Acad., 4\%, p. 171; 1911. 
TABLE 3.-Transition temperatures determined by the conductance method compared with those determined by the equilibrium method

\begin{tabular}{|c|c|c|}
\hline Mixture & $\begin{array}{c}\text { Transi- } \\
\text { tion } \\
\text { tempera- } \\
\text { ture by } \\
\text { conduct- } \\
\text { ance }\end{array}$ & $\begin{array}{c}\text { True } \\
\text { transi- } \\
\text { tion } \\
\text { tempers- } \\
\text { ture }\end{array}$ \\
\hline $\begin{array}{l}\mathrm{Na}_{2} \mathrm{SO}_{4} \cdot 10 \mathrm{H}_{2} \mathrm{O}+\mathrm{Na}_{2} \mathrm{SO}_{4} \\
\mathrm{Na}_{2} \mathrm{Cr}_{4} \cdot 10 \mathrm{H}_{2} \mathrm{O}+\mathrm{Na}_{2} \mathrm{CrO} .6 \mathrm{H}_{2} \mathrm{O}\end{array}$ & $\begin{array}{l}{ }^{\circ} C . \\
32.33 \\
19.51\end{array}$ & $\begin{array}{l}{ }^{\circ} C . \\
32.384 \\
19.525\end{array}$ \\
\hline
\end{tabular}

Washington, November 21, 1928. 